Edubiotik: Jurnal Pendidikan, Biologi dan Terapan
ISSN 2528-679X (print), ISSN 2597-9833 (online)
Vol. 6, No. 01, February 2021, pp. 49-57
Available online at:
http:/lejurnal.budiutomomalang.ac.id/index.php/edubiotik

Research Article

OPEN ACCESS

\title{
Analysis of learning difficulties in vertebrate zoology during the COVID-19 pandemic based on student learning styles
}

\author{
Wachidatul Linda Yuhanna ${ }^{1 *}$, Riyanto ${ }^{2}$, Nurmala Hindun² \\ 'Biology Education Department, Universitas PGRI Madiun, Madiun, Indonesia \\ 2Biology Education Department, IKIP Budi Utomo, Malang, Indonesia \\ Email: linda.yuhanna@unipma.ac.id*, riyanto.arkum.27.83@gmail.com, nurmalahindun01@gmail.com
}

\begin{tabular}{|c|c|}
\hline Article Information & ABSTRACT \\
\hline $\begin{array}{l}\text { Submitted: } 2020-12-28 \\
\text { Accepted: } 2021-05-02 \\
\text { Published: } 2021-05-04\end{array}$ & $\begin{array}{l}\text { Vertebrate zoology lectures during the COVID-19 pandemic brought about a } \\
\text { transformation from face-to-face lecture systems to online self-learning. Students } \\
\text { with various learning styles experience difficulties in studying vertebrate zoology } \\
\text { courses. The purpose of this study was to analyze the learning difficulties of the } \\
\text { COVID-19 pandemic zoology vertebrate course as a whole and based on student } \\
\text { learning styles. This research was conducted at the University of PGRI Madiun } \\
\text { and IKIP Budi Utomo in May } 2020 \text {. The number of respondents was } 140 \text { students } \\
\text { of the Biology Education Department. This type of research is qualitative research } \\
\text { with a survey method. The instrument used was a questionnaire analysis of } \\
\text { vertebrate zoological learning difficulties using the google form. Data were } \\
\text { analyzed descriptively qualitatively. The results showed that the learning } \\
\text { difficulties of students, in general, were related to the understanding of scientific } \\
\text { names as much as } 71 \% \text { and the fulfillment of teaching materials as much as } 51 \% \text {. } \\
\text { The learning difficulties of students with a visual learning style consisted of } \\
\text { understanding scientific names ( } 69 \%) \text { and the fulfillment of teaching materials } \\
\text { (57\%). The learning difficulties of students with auditory learning styles consist of } \\
\text { understanding scientific names ( } 81 \%) \text {. The learning difficulties of students with the } \\
\text { kinesthetic learning style consisted of understanding scientific names ( } 67 \%) \text {. This } \\
\text { study concludes that students' difficulties are dominated by understanding } \\
\text { scientific names and the availability of teaching materials. }\end{array}$ \\
\hline & Keywords: Learning difficulties; vertebrate zoology; learning styles \\
\hline Publisher & How to Cite \\
\hline $\begin{array}{l}\text { Biology Education Department } \\
\text { IKIP Budi Utomo, Malang, Indonesia }\end{array}$ & $\begin{array}{l}\text { Yuhanna, W. L., Riyanto, \& Hindun, N. (2021). Analysis of learning difficulties in } \\
\text { vertebrate zoology during the COVID-19 pandemic based on student learning } \\
\text { styles. Edubiotik: Jurnal Pendidikan, Biologi dan Terapan, 6(01) 49-57. } \\
\text { https://doi.org/10.33503/ebio.v6i01.1209 }\end{array}$ \\
\hline 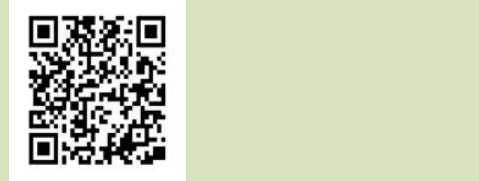 & $\begin{array}{l}\text { Copyright ( } 2021 \text {, Yuhanna et al. } \\
\text { This is an open access article under the CC-BY-SA license } \\
\text { (c) (i) (-) }\end{array}$ \\
\hline
\end{tabular}

\section{INTRODUCTION}

Vertebrate zoology is a course that studies the introduction, classification and taxonomy of vertebrate animals. This course is a compulsory subject for students of the biology education study program. This course is presented in the form of material delivery, practicum and field visits. The integrated field lectures that are carried out will provide opportunities for students to explore objectivity in 
a full and authentic way (Ibrahim et al., 2018). The material discussed in this course includes basic taxonomy, nomenclature and classification of vertebrates, pisces, amphibians, reptiles, aves, and mammals (Faizah et al., 2013). Students in taking this course are expected to have theoretical abilities and their application in everyday life (Yuhanna \& Retno, 2018). Students who take the Vertebrate Zoology course this year are also expected to be able to adapt to the current lecture patterns during the COVID19 pandemic.

The COVID-19 pandemic since March 2020 has brought significant changes to all aspects of life. The COVID-19 pandemic has adverse effects on education including, learning disruptions, and decreased access to education and research facilities, job losses and increased student debts (Onyema, 2020). The change in the educational paradigm, which was originally implemented face-to-face, has transformed into online learning or in a full network. This has a significant impact on the learning process and student learning outcomes in the vertebrate zoology course. Changes that are sudden and not followed by readiness in terms of infrastructure, mental and study habits bring challenges for lecturers and students (Kurniawan et al., 2020; Yustina et al., 2020). The learning process in the vertebrate zoology course also undergoes a transformation in practicum methods and procedures. Students are directed to self-study at home with a pattern of adapting to new habits.

The problem that arises in learning vertebrate zoology during the COVID-19 pandemic is that students are not ready and used to learning independently and completely online. Students' digital literacy skills are still low, especially in accessing activities, searching for digital literature and creating digital content as a form of task fulfillment and evaluation (Yustina et al., 2020). Students do not understand the material of vertebrate zoology because the learning system is not optimal. In addition, there is also a feeling of anxiety about COVID-19 which results in students being passive, less productive and less motivated in learning. Each student has their own weaknesses and challenges according to their abilities and learning styles.

Every student has different characteristics and learning styles in understanding a material (Kaur et al., 2018). Student learning styles reflect the character that is built. Different learning styles show the fastest and best way for each individual to be able to absorb information from outside himself (Papilaya \& Huliselan, 2016). This difference in learning styles also affects the student's response to receiving the transformation of the learning model during the pandemic. Learning styles based on the ability of the senses to carry out their activities consist of 3 groups, namely visual learning styles, auditory learning styles and kinesthetic learning styles (Wahyuni, 2017). An understanding of student learning styles can help lecturers / educators to facilitate students in learning (Kholid et al., 2016).

Visual learning style is a learning style by seeing, observing or looking at, ojek as a learning resource (Rijal \& Bachtiar, 2015; Wahyuni, 2017). The most dominant sense is the sense of sight. This type of visual learning style has the characteristic of liking neatness and skill, if speaking tends to be faster, likes to make careful planning for the long term, very thorough to the details. Students with visual learning styles remember more easily by seeing the visualization of an object. Students of this type are not easily distracted by the conditions of the environment in which they are studying, because their main focus is observing objects (Ningrum et al., 2018).

Auditory learning style is a learning style that is dominated by the sense of hearing (Rijal \& Bachtiar, 2015; Wahyuni, 2017). This learning style focuses on what is heard and obtained from the results of discussion and brainstrorming. Students with auditory learning styles are very comfortable with what to tell, read aloud and are good at speaking. What is uncomfortable is the disturbance or disruption of the 
learning environment (Wahyuni, 2017). Students with this learning style do not like to write and see real objects.

The third learning style is kinesthetic. Kinesthetic learning style is a learning style that is easier to absorb information by moving, doing, and touching something that provides information (Papilaya \& Huliselan, 2016; Wahyuni, 2017). This learning style really likes being involved in real processes, for example in product design practicums and field visits. Hands-on implementation is needed to support students' long term memory. The characteristics of this learning style are students need to have real experience, memorize by walking, dynamic and lots of physical activity (Rijal \& Bachtiar, 2015).

Learning difficulties in the vertebrate zoology course need to be described in detail according to the learning style of the student. Each learning style has different activities in learning a concept. So that the types of difficulties and learning support needs are also different (Nursasono et al., 2020). This condition must be understood by lecturers so as not to generalize solutions to deal with student learning difficulties. The urgency of this study is that an analysis of student learning difficulties is indispensable to determine the conditions and needs of students studying vertebrate zoology during the COVID-19 pandemic. Lecturers need to identify, record, and analyze learning difficulties as material to be used as a study of lecture development during the pandemic. Based on interviews and observations in the previous semester. The majority of student learning difficulties in taking vertebrate zoology courses are the availability of teaching materials, mastery of material, understanding scientific names, applying practicum and making practicum reports.

The objectives of this study were 1) To analyze the general learning difficulties of students in the vertebrate zoology course during the COVID-19 pandemic. 2) Analyzing student learning difficulties in the vertebrate zoology course based on learning styles during the COVID-19 pandemic. So, this data can be used as material for lecturers to study to improve the quality of vertebrate zoology lectures in the next semester.

\section{RESEARCH METHODS}

This type of research is a qualitative research with a survey method. This research was conducted at the Universitas PGRI Madiun and IKIP Budi Utomo. The research was conducted in May 2020. The number of respondents was 140 students of the Biology education study program. The survey method is carried out in stages 1) Formulating research problems and determining the objectives of the survey. 2) Determine concepts and hypotheses and dig literature. 3) Taking population and samples. 4) Making questionnaires and instruments. 5) Retrieval of data using Google form. 6) Data processing. 7) Analysis and conclusion.

The instrument used was a questionnaire to analyse the learning difficulties of vertebrate zoology which was developed by the author. Authors determine the aspects of learning difficulties from the observation sheets and interviews in the previous semester. This questionnaire contains 7 questions related to student learning difficulties while taking the vertebrate zoology course during the COVID-19 pandemic. Aspects that are measured are learning difficulties in terms of the availability of teaching materials, mastery of the material, understanding scientific names, implementing practicum and making practicum reports. Each aspect is stated to have a high difficulty level if it is more than a percentage of $50 \%$ and a low (easy) difficulty level is below a percentage of $50 \%$. The collected data were analysed descriptively qualitatively to produce relevant conclusions. 


\section{FINDINGS AND DISCUSSION}

The study of vertebrate zoology during the COVID-19 pandemic was carried out online and independently. Students understand the material using digital sources. The data shows that 140 respondents were involved in this study by filling out a questionnaire using google form. Researchers did not look at the zoological learning activities of vertebrates directly. The composition of respondents based on learning styles is stated in Figure 1. Learning styles are related to the success of the learning process (Abidoye \& Olorundare, 2020). Figure 1 shows that the visual learning style is $67 \%$, auditory is $22 \%$ and kinesthetic is $11 \%$. This data shows that most students have a tendency to visual learning styles. Analysis of student learning difficulties in taking vertebrate zoology courses during a pandemic aims to evaluate lectures. This data is also used to determine follow-up efforts to improve the learning process. The survey data for student learning difficulties includes 5 aspects, namely teaching materials, mastery of the material, understanding scientific names, implementing practicum and making practicum reports. The ability of students to learn is unique. The basic consideration for determining these five aspects is by reference studies, unstructured interviews and discussions with students. The way students understand the material also depends on their tendency to learn. The learning process involves the interaction between human senses, learning resources and the surrounding environment. Learning styles also have an effect on students' cognitive abilities (Kaur et al., 2018; Rijal \& Bachtiar, 2015).

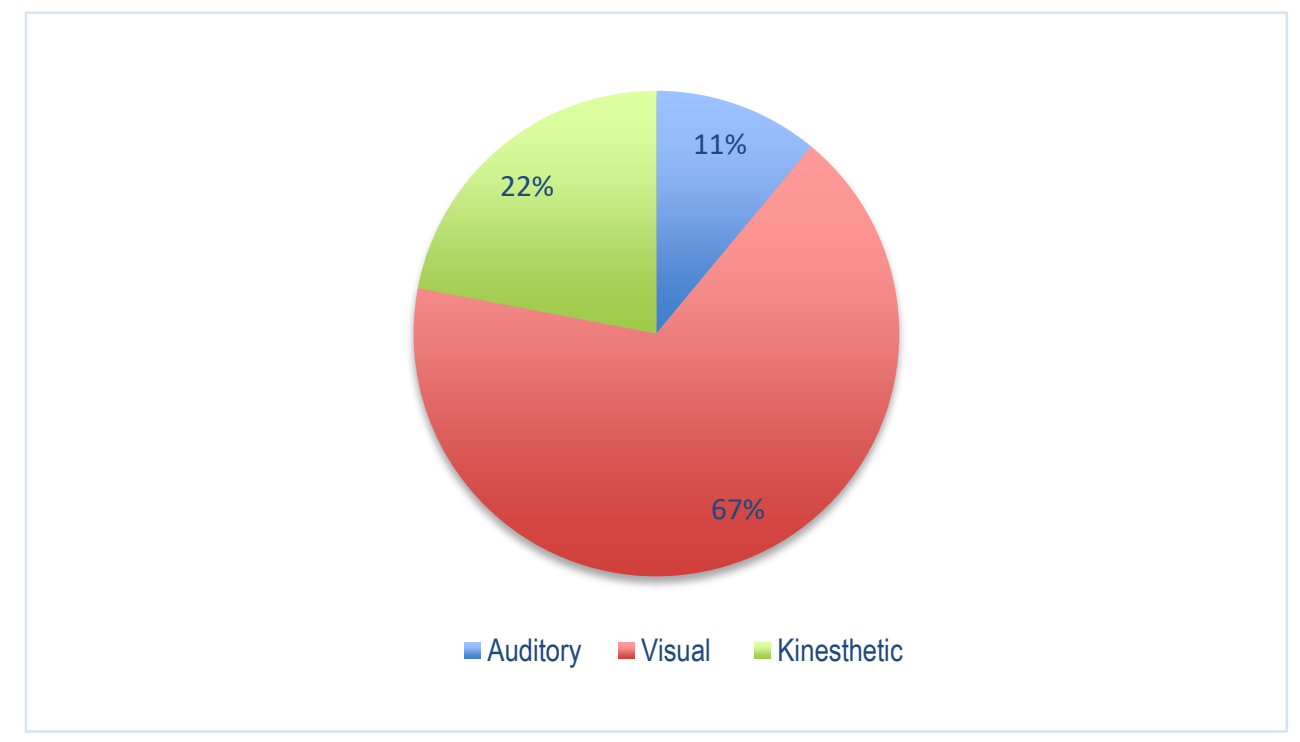

Figure 1. Composition of The Respondent's Learning Style

The graph of the percentage of learning difficulties for vertebrate zoology is as shown in Figure 2. Based on the graph in Figure 2, the highest level of difficulty of all respondents is the understanding of scientific names as much as $71 \%$ and teaching materials as much as $51 \%$. The difficulty level of the material aspect (16\%), practicum (25\%) and practicum report (21\%) is not considered a high level difficulty because it is below $50 \%$. The scientific name is an integral component of the discussion of vertebrate taxonomy. The binomial system of nomenclature was coined by taxonomists to equate perceptions around the world. Memorizing and understanding scientific names is difficult for some students. In addition to the use of foreign terms that are difficult for students to understand, scientific names also have their own rules (Kurniawan et al., 2015). Understanding of scientific names is very necessary to maintain scientific communication in describing a species. 
These findings have implications for lecturers to make formulations that make it easier for students to learn the scientific names of vertebrate animals. The second difficulty is in the aspect of the availability of teaching materials. Teaching materials are an important component to support learning. Students need teaching materials as learning resources that contain materials and learning outcomes in the vertebrate zoology course. Fulfillment of current teaching materials is very necessary for understanding concepts and increasing student knowledge (Yuhanna \& Retno, 2018).

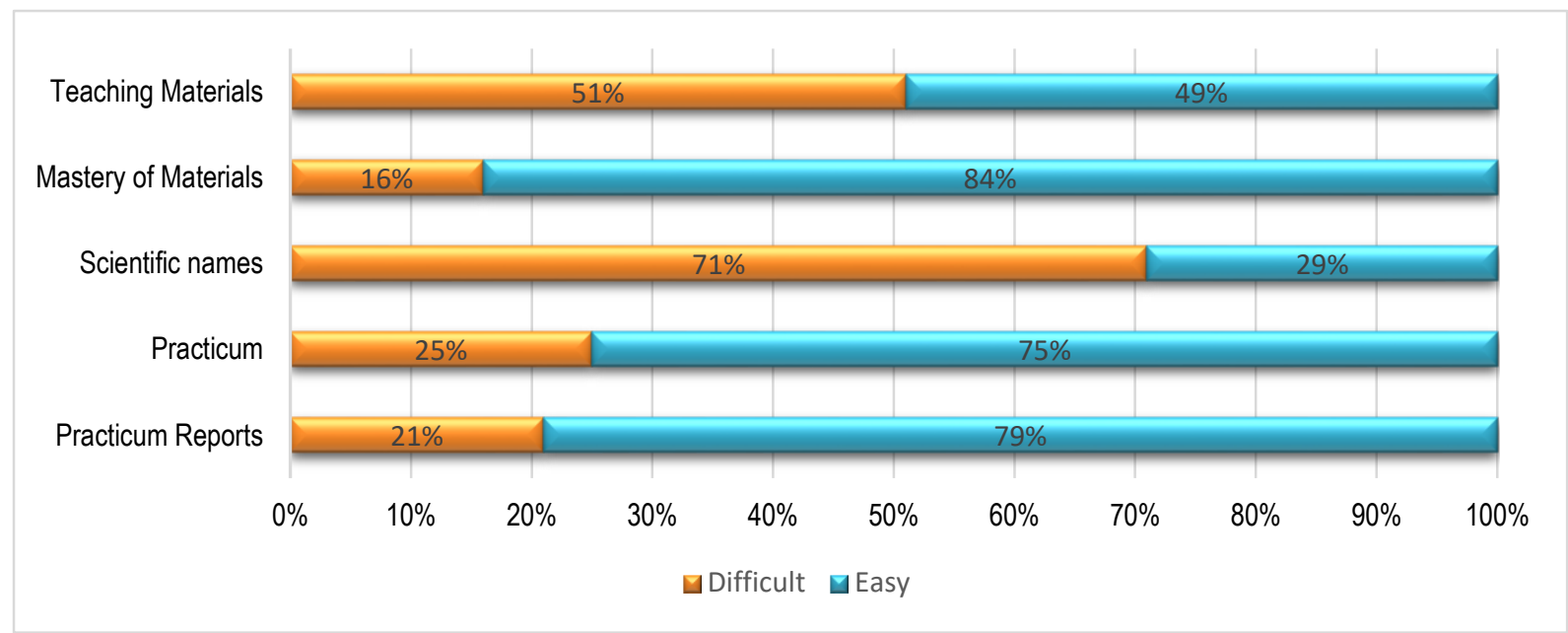

Figure 2. Percentage of Student Learning Difficulties in The Vertebrate Zoology Course during the COVID-19 Pandemic

Students with a visual learning style have a distinctive character. Visual learning styles emphasize learning abilities by seeing and observing learning resources. Students in obtaining information tend to be interested in looking at writing, pictures, posters, diagrams, graphics, and so on (Kanadlı, 2016). The learning difficulties of students with a visual learning style in the vertebrate zoology course are presented in Figure 3. The highest difficulty level for students with a visual learning style is learning scientific names as much as $69 \%$ and teaching materials as much as $57 \%$. The percentage for scientific names and teaching materials is high and dominates more than $50 \%$ of students.

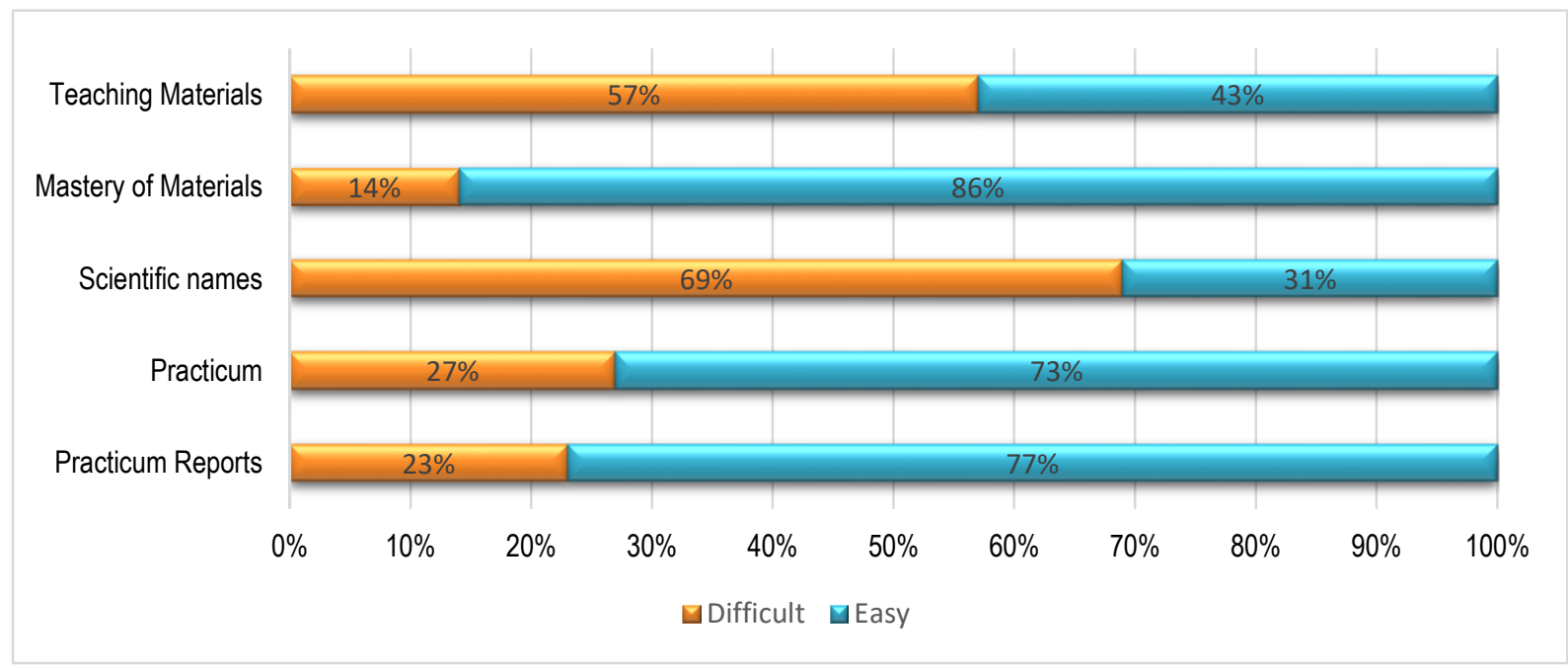

Figure 3. Percentage of Student Learning Difficulties in The Vertebrate Zoology Course During The COVID-19 Pandemic Based on Visual Learning Styles 
The practical aspect is $27 \%$, the practicum report is $23 \%$ and mastery of the material is $14 \%$, which shows that the level of difficulty is low. The scientific name is a mandatory thing that students must understand in taking the vertebarta zoology course (Faizah et al., 2013; Kurniawan et al., 2015). Students with a visual learning style need to read scientific names to remember and understand. If the scientific name is only conveyed briefly, it is not surprising that students have difficulty. Scientific names can also be understood by recording and seeing the visual manifestation of species in more detail (Kurniawan et al., 2015; Yuhanna \& Retno, 2018). Lecturers must respond to this learning difficulty by formulating integrated scientific name learning in teaching materials that are read by students with a visual learning style.

The availability of teaching materials during a pandemic is important to support independent learning and support student competence. Students with visual learning styles usually learn optimally by observing objects directly. Students with this learning style tend to need to see learning resources in real terms. This type of student really likes to read material and observe existing learning resources. The availability of teaching materials is needed for students with a visual learning style. Teaching materials serve to help students remember concepts, shapes, colors and artistic understanding. Teaching materials are also used for deeper understanding of concepts by reading them over and over again. The more frequency the student reads, the material will also enter the student's long term memory. The availability of this teaching material needs a response from the lecturer to provide independent learning facilities for students. The development of teaching materials can also be directed at local potential.

Auditory learning styles have a tendency to use the listener's senses to absorb information. Students with auditory learning styles are more comfortable listening to explanations from other people to learn something. Students with the auditory learning type also prefer to talk, discuss and explain in detail the concepts discussed (Fetalvero, 2017). Figure 4 shows the percentage of learning difficulties in students with auditory learning styles. The highest level of difficulty is in understanding scientific names as much as $81 \%$. While the other 4 difficulties consisted of $39 \%$ teaching materials, $19 \%$ practicum, $19 \%$ practicum reports and $16 \%$ mastery of material. These four types of difficulties are not considered to be difficulties, because the percentage is below $50 \%$.

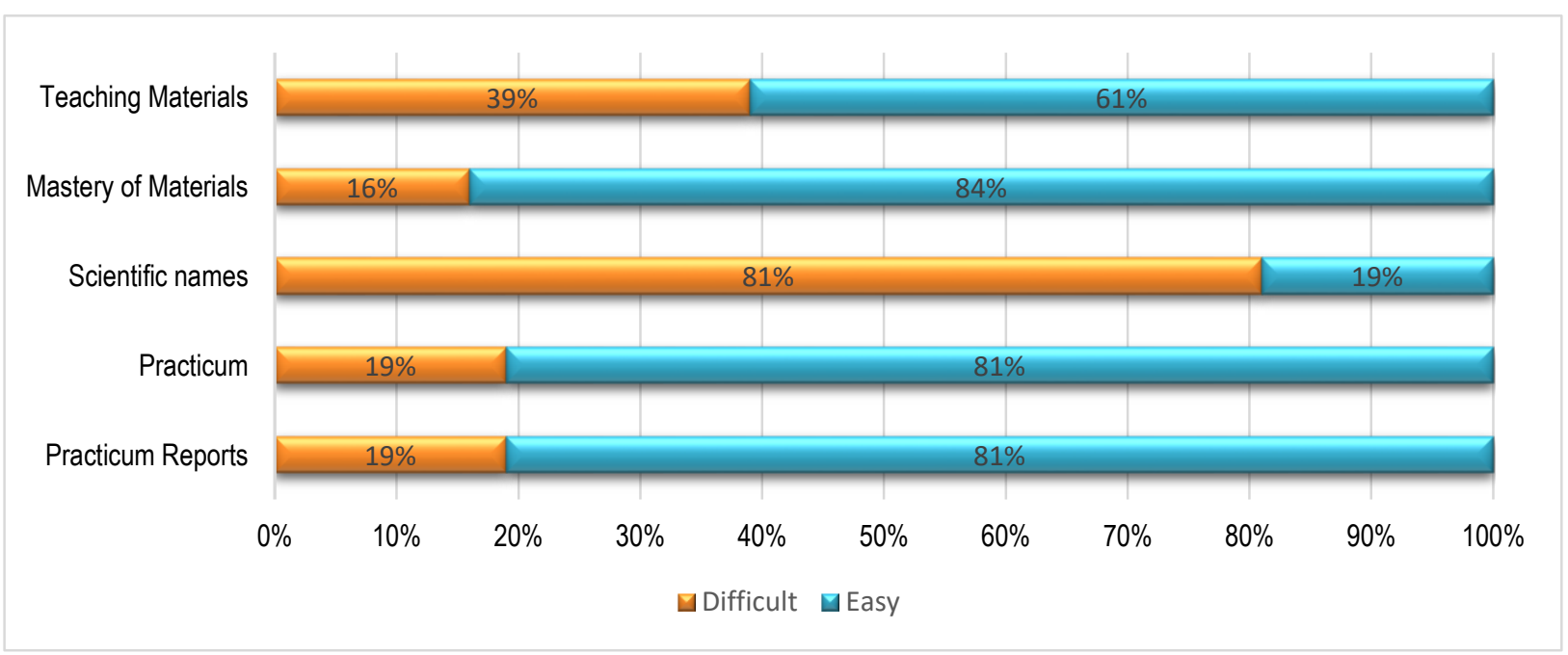

Figure 4. Percentage of Student Learning Difficulties in The Vertebrate Zoology Course During The COVID-19 Pandemic Based on Auditory Learning Styles 
Based on the data in Figure 4, the main focus is directed at the difficulty of understanding scientific names. This percentage indicates that most students with auditory learning styles are not relevant to the existing method of reading scientific names. Students with auditory learning styles need innovation in learning scientific names. So far, the scientific name is not specifically presented in certain chapters, but it is implied in the material in each class of vertebrates consisting of pisces, amphibians, reptiles, mammals and aves. Students with auditory learning styles do have weaknesses in finding, understanding and studying information implied in a learning resource.

Students with the auditory learning type rely on listening and discussion activities to remember concepts including scientific names. The relevant method for students with auditory learning styles is cooperative learning, discussions, presentations and group assignments (Harie, 2016). In addition, scientific names can also be transformed into digital content that can be heard by students. The use of multimedia, web and android-based information technology is very possible to support the understanding of scientific names for students with auditory learning styles (Kurniawan et al., 2015).

Kinesthetic learning styles are characterized by the process of absorbing information through physical movements (Permana, 2016). Students with this learning style really like movement and physical activity in understanding a concept. Students will make many movements and actively use existing media and learning resources. Practical learning is very popular with students with this learning style. Figure 5 shows that among students with a kinesthetic learning style, the greatest difficulty experienced is understanding the scientific name as much as $67 \%$. Other difficulties are described successively, namely the difficulty of teaching materials as much as $44 \%$, material $28 \%$, practicum $22 \%$ and practicum reports as much as $17 \%$. The four aspects other than scientific names do not include learning difficulties, because the percentage is below $50 \%$. Students with kinesthetic learning styles do not experience difficulties in practicum and making practicum reports, because basically students with this learning style are very relevant to practicum activities. This learning style needs the support of relevant practicum instructions (Karmila \& Khaerati, 2016; Permana, 2016). Students with this learning style during the pandemic were able to adapt to the use of virtual laboratories and independent practicums. Independent practicum is an alternative for fulfilling science process skills competencies during the COVID-19 Pandemic (Putri et al., 2020).

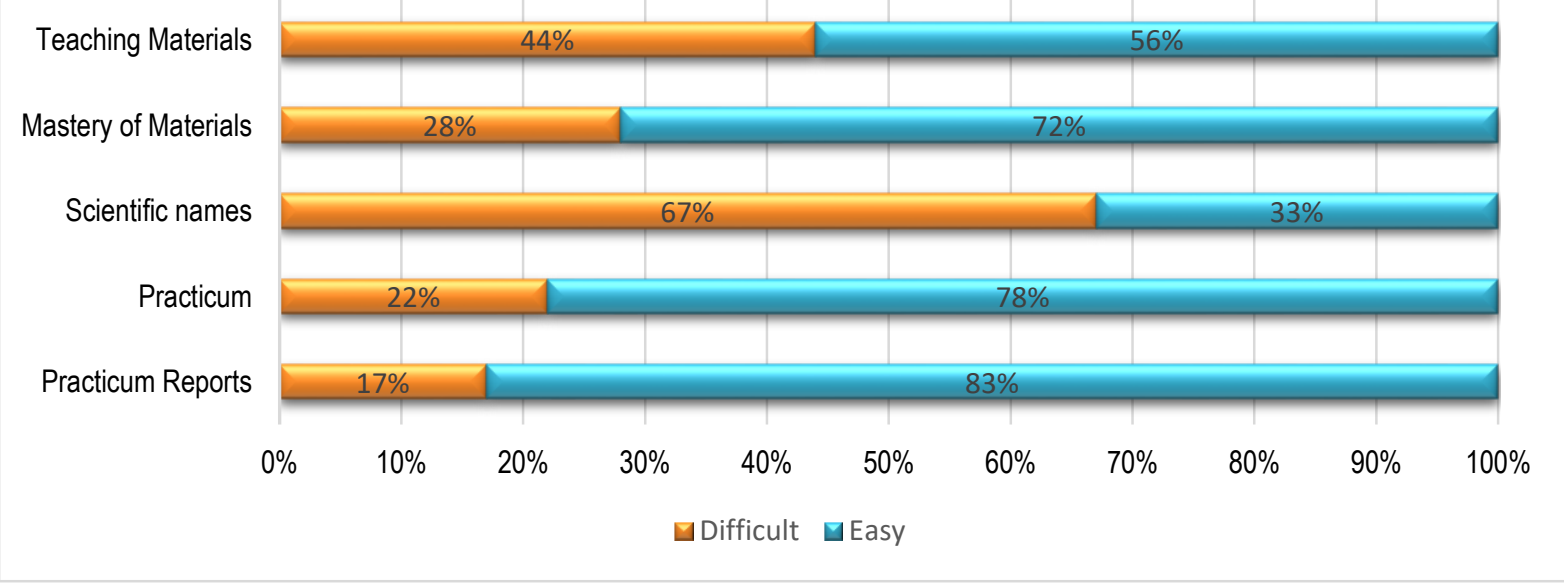

Figure 5. Percentage of Student Learning Difficulties in The Vertebrate Zoology Course During The COVID-19 Pandemic Based on Kinesthetic Learning Styles 
Each student with a different learning style has their own difficulties. Like students with auditory and visual abilities, Latin names are also a scourge for students with kinesthetic learning styles. Latin names are a problem for various students, because Latin names are not interpreted as a movement. Other field data shows that lecturers in the vertebrate zoology course provide material scientific names in writing in books and teaching materials. This causes students with a kinesthetic learning style to understand and understand the Latin names of many animals. Understanding Latin names in vertebrate zoology is not only limited to material exposure, but is also reflected in the activities and learning activities that must be carried out. So that students can explore learning resources by building their knowledge through direct interaction with their experiences and environment.

\section{CONCLUSION}

Based on the data presentation, it can be concluded that the learning difficulties of students in general in the vertebrate zoology course during the COVID-19 pandemic were related to the understanding of scientific names as much as $71 \%$ and the fulfillment of teaching materials as much as $51 \%$. The learning difficulties of students with a visual learning style consisted of understanding scientific names $(69 \%)$ and the fulfillment of teaching materials (57\%). The learning difficulties of students with the auditory learning style consisted of understanding scientific names (81\%) The learning difficulties of students with the kinesthetic learning style consisted of understanding scientific names (67\%). The impact of the results of this study is the basis for determining the strategy for the development of vertebrate zoology lectures. This study becomes the basis for meeting the learning needs of students based on the analysis of learning difficulties. Suggestions for further research are a solution to student learning difficulties.

\section{ACKNOWLEDMENT}

The author would like to thank the State University of Malang and all student respondents from the Universitas PGRI Madiun and IKIP Budi Utomo Malang.

\section{REFERENCES}

Abidoye, F. O., \& Olorundare, A. S. (2020). The Correlation between Learning Styles and Biology Learning Performance of Nigerian Students. JPBI (Jurnal Pendidikan Biologi Indonesia), 6(1), 107112. https://doi.org/10.22219/jpbi.v6i1.11206

Faizah, U., Ambarwati, R., \& Haryono, T. (2013). Etnozoologi dalam pembelajaran taksonomi vertebrata di Jurusan Biologi FMIPA Unesa. Prosiding Seminar Biologi, 1-9. Retrieved from http://jurnal.fkip. uns.ac.id/index.php/prosbio/article/view/3088

Fetalvero, E. G. (2017). Consensus-based education: its effect on college students' achievement in bioenergetics as moderated by gender and learning styles. Journal of Baltic Science Education, 16(4), 533-548. Retrieved from http://www.scientiasocialis.It/jbse/?q=node/587

Harie, S. (2016). Pengaruh metode pembelajaran dan gaya belajar terhadap kemampuan berpikir kritik biologi. Formatif: Jurnal IImiah Pendidikan MIPA, 5(3), 257-267. https://doi.org/10.30998/formatif. v5i3.651

Ibrahim, Y., K Surtikanti, H., \& Riandi, R. (2018). Kuliah lapangan terpadu berbasis inkuiri untuk meningkatkan penguasaan konsep mahasiswa Pendidikan Biologi. BIOSFER: Jurnal Biologi dan Pendidikan Biologi, 2(2). https://doi.org/10.23969/biosfer.v2i2.854

Kanadlı, S. (2016). A meta-analysis on the effect of instructional designs based on the learning styles models on academic achievement, attitude and retention. Kuram ve Uygulamada Egitim Bilimleri, 16(6), 2057-2086. https://doi.org/10.12738/estp.2016.6.0084 
Karmila, F., \& Khaerati. (2016). Pengembangan penuntun tugas kinerja praktikum mahasiswa di laboratorium biologi. Prosiding Seminar Nasional, 2(1). Retrieved from https://journal.uncp.ac.id/ index.php/proceding/article/view/479

Kaur, G., Saini, S., \& Vig, D. (2018). Gender differentials in the impact of learning styles on metacognitive skills of rural adolescents. Asian Journal of Home Science, 13(1), 151-157. https://doi.org/10.15740/ has/ajhs/13.1/151-157

Kholid, M. N., Pangestika, A. I., \& Harta, I. (2016). Identification of learning styles in terms of gender differences and emotional quotient levels. 109-114. Retrieved from http://eprints.ums.ac.id/43914/ 14/02.NASKAH\%20PUBLIKASI.pdf

Kurniawan, D., Aristoteles, \& Amirudin, A. (2015). Pengembangan aplikasi sistem pembelajaran klasifikasi (taksonomi) dan tata nama ilmiah (binomial nomenklatur) pada kingdom plantae (tumbuhan) berbasis android. Jurnal Komputasi, 3(2), 120-128. Retrieved from https://jurnal.fmipa. unila.ac.id/index.php/komputasi/article/view/1143

Kurniawan, R. P., Damopolii, I., Silvia, H. \& Sirait, K. (2020). The correlation between biology teacher learning strategies during the COVID-19 pandemic on student motivation. 299-305. Retrieved from https://proceedings.aecon.ump.ac.id/index.php/aecon/article/view/49

Ningrum, I. D., Yulhendri, Y., Marwan, M., \& Rahmidani, R. (2018). The influence of organization participation and learning styles on studentsr academic achievement. PICEEBA 2018, 589-595. https://doi.org/10.2991/piceeba-18.2018.9

Nursasono, N., Kasman, R., Iffan, D., \& Kamiri, K. (2020). Global conferences series: identification of student learning style in determining learning media using expert systems. Global Conference Series: Social Sciences, Education and Humanities (GCSSSEH) 5, 22-26. Retrieved from https://series.gci.or.id/article/339/16/psshers-2020

Onyema, E. M. (2020). Impact of coronavirus pandemic on education. Journal of Education and Practice, 11(13), 108-121. https://doi.org/10.7176/jep/11-13-12

Papilaya, J. O., \& Huliselan, N. (2016). Identifikasi gaya belajar mahasiswa. Jurnal Psikologi Undip, 15(1), 56. https://doi.org/10.14710/jpu.15.1.56-63

Permana, A. D. I. (2016). Pengaruh gaya belajar dan motivasi belajar mahasiswa terhadap kemampuan belajar ilmu alamiah dasar. Jurnal Formatif, 6(3), 276-283. Retrieved from https:/www.neliti.com/id/

Putri, E. K., Wisanti, Ambarwati, R., Rahayu, D. A., \& Khaleyla, F. (2020). Biology online classes during COVID-19 pandemic in Indonesia. Proceedings of the International Joint Conference on Science and Engineering (IJCSE 2020), 176-180. https://doi.org/10.2991/aer.k.201124.033

Rijal, S., \& Bachtiar, S. (2015). Hubungan antara sikap, kemandirian belajar, dan gaya belajar dengan hasil belajar kognitif siswa. Jurnal Bioedukatika, 3(2), 15. https://doi.org/10.26555/bioedukatika. v3i2.4149

Wahyuni, Y. (2017). Identifikasi gaya belajar (visual, auditorial, kinestetik) mahasiswa Pendidikan Matematika Universitas Bung Hatta. Jurnal Penelitian dan Pembelajaran Matematika, 10(2), 128132. https://doi.org/10.30870/jppm.v10i2.2037

Yuhanna, W. L., \& Retno, R. S. (2018). Pengembangan modul zoologi vertebrata terintegrasi scientific inquiry. Proceeding Biology Education Conference, 15(1), 614-619. Retrieved from https://jurnal. uns.ac.id/prosbi/article/view/32636

Yustina, Syafii, W., \& Vebrianto, R. (2020). The effects of blended learning and project-based learning on pre-service biology teachers' creative thinking skills through online learning in the COVID-19 pandemic. Jurnal Pendidikan IPA Indonesia, 9(3), 408-420. https://doi.org/10.15294/jpii.v9i3.24706 